\title{
INVESTMENT ADVISERS AND DISCLOSURE OF AN INTENT TO TRADE*
}

The Investment Advisers Act of 1940, dormant for two decades, has recently received extensive legislative, administrative and judicial attention. Shortly after Congress amended the act in 1960, the Securities and Exchange Commission sought an interpretation of the unamended sections which would require Capital Gains Research Bureau, an investment adviser, to disclose fully its financial interest or intent to trade in a security which it recommends. ${ }^{1}$ Neither the district court nor the Court of Appeals for the Second Circuit was willing to interpret the act so broadly. The decisions of the two courts, though holding only that a preliminary injunction was not warranted, raise questions concerning not only how great an obligation of disclosure the act imposes upon investment advisers, but also the extent to which a court asked to issue an injunction should be influenced by the fact that the Commission possesses the power to proscribe by rule the conduct in question.

When the Investment Advisers Act was originally enacted in 1940, relatively little was known about the practices of investment advisers; in fact, the act was in large part designed to acquire information about the industry. ${ }^{2}$ It required that persons giving, for compensation, advice or information concerning the value of securities register with the SEC. ${ }^{3}$ The act specifically defined a few unlawful practices, and one provision, section 206, proscribed fraudulent activities generally. ${ }^{4}$ The principal means of enforcement was by injunction, which the SEC could obtain from a district court upon a showing

*SEC v. Capital Gains Research Bureau, 300 F.2d 745 (2d Cir. 1961).

1. SEC v. Capital Gains Research Bureau, 191 F. Supp. 897 (S.D.N.Y. 1961), aff'd 300 F.2d 745 (2d Cir. 1961), reargued en banc Feb. 22, 1962, N.Y. Times, Feb. 18, 1962, § 3 (Finance), p. 1, col. 1. The defendants in the case were both the corporate adviser and its sole shareholder. The decision on reargument had not been issued at press time.

The statute had not been a wholly dead letter for twenty years, but few proceedings had been instituted under it. 3 Loss, Securitres Regulations 1515 (2d ed. 1961).

2. Hearings on Investment Trusts and Investment Companies Before a Subcommittee of the Senate Committee on Banking and Currency, 76th Cong., 3d Sess. 48 (1940) (statement of Mr. David Shenker, Chief Counsel for the SEC's Investment Trust Study).

3. 54 Stat. 847,850 (1940), 15 U.S.C. § $80 \mathrm{~b}-2(11)$ (1958), as amended, 15 U.S.C. § 80b-3 (Supp. II, 1961). Publications of a "general and regular circulation" are exempt, as are banks and certain professions. So long as brokers and dealers make no special charge for advice given to their clients and customers, they need not register. For general descriptions of the act see Loomis, The Securities Exchange Act of 1934 and the Investinent Adviscrs Act of 1940, 28 Geo. WAsh. L. Rev. 214, 244-49 (1959) and 2 Loss, Securities RegulaTIONs 1393-1417 (2d ed. 1961), 3 id.1515-18.

4. 54 Stat. 852 (1940), as amended, 15 U.S.C. § 80b-6 (Supp. II, 1961). Also, an adviser may not enter into an advisory contract which provides for compensation on the basis of the capital appreciation of the securities managed, 54 Stat. 852 (1940), as amended, 15 U.S.C. $80 \mathrm{~b}-5$ (Supp. II, 1961) ; nor may he give advice regarding a transaction in which he plays some role other than adviser, unless he discloses his dual capacity. 54 Stat. 852 (1940), as amended, 15 U.S.C. \$ 80b-6(3) (Supp. II, 1961). 
that the adviser had violated the act..$^{5}$ Also, the Commission could suspend or revoke an adviser's registration, but only after the adviser had been enjoined or found guilty of a crime. ${ }^{6}$ In September 1960, Congress amended the act to provide for a more comprehensive regulation of advisory activities. ${ }^{7}$ The Commission was granted the power to suspend or revoke registration upon its own finding that the adviser has violated the act ${ }^{8}$ and, more importantly, extensive rule-making authority. ${ }^{9}$ Subsection (4), encompassing this authority, was joined with the original antifraud provisions of section 206 , which now provide:

It shall be unlawful for any investment adviser . . .

(1) to employ any device, scheme, or artifice to defraud any client or prospective client;

(2) to engage in any transaction, practice, or course of business which operates as a fraud or deceit upon any client or prospective client; ...

(4) to engage in any act, practice, or course of business which is fraudulent, deceptive, or manipulative. The Commission shall, for the purposes of this paragraph (4) by rules and regulations define, and prescribe means reasonably designed to prevent, such acts, practices, and courses of business as are fraudulent, deceptive, or manipulative. ${ }^{10}$

Although two of the alleged violations in Capital Gains occurred after the effective date of the amendment, ${ }^{11}$ the SEC did not advance the new subsection (4) as a ground for its action. The first sentence- "It shall be unlawful to engage in any act, practice, or course of business which is fraudulent, deceptive, or manipulative"-will probably be found to be "self-operative"; that is, a court might issue an injunction under it even if the Commission had not previously promulgated a rule defining and prohibiting the conduct in question. ${ }^{12}$ If this view is adopted, the old subsections (1) and (2) will have

5. 54 Stat. 854 (1940), as amended, 15 U.S.C. $\S 80$ b-9 (e) (Supp. II, 1961). An injunction could also be obtained when a person "is about to" violate the act.

6. The exercise of this power was subject to the Commission's finding that revocation or suspension was in the public interest and that the convictions or injunctions had been rendered in the context of dealings in securities. 54 Stat. 851 (1940), 15 U.S.C. $\S 80 \mathrm{~b}-3$ (d) (1958).

7. 74 Stat. $885-88$ (1960), 15 U.S.C. $\$ \$ 80 \mathrm{~b}-2$ to -18 (a) (Supp. II, 1961).

8. Registration may be suspended or revoked for violations of other securities statutes as well, but all such violations must be "willful." 74 Stat. 885 (1960), 15 U.S.C. \& S0b-3(d) (D) (Supp. II, 1961).

9. 74 Stat. 887 (1960), 15 U.S.C. \$ 80b-6(4) (Supp. II, 1961).

10. 74 Stat. 887 (1960), 15 U.S.C. § 80b-6 (Supp. II, 1961).

11. The effective date of the amendments was September 13, 1960, 74 Stat. 888 (1960); the last two bulletins involved in the suit were sent out October 14, 1960, and November 1 , 1960, Brief for Appellant, Appendix, pp. 19, 20.

12. 3 Loss, Securitres Regulations 1425 (2d ed. 1961) (interpreting $\$ 15$ (c) (1) of the Securities Exchange Act). Presumably Professor Loss's characterization of the amendment's parent provision carries over to the amendment. 
relevance only to acts committed before September 1960, for subsection (4) clearly encompasses any conduct covered by the original provisions. ${ }^{13}$

Each month Capital Gains Research Bureau distributes to its approximately five thousand clients a bulletin describing and recommending a stock it considers promising for long-term capital investment. ${ }^{14} \mathrm{On}$ at least five different occasions in 1960, the adviser bought shares of a stock which he recommended shortly thereafter; less than two weeks after the mailing of the recommending bulletin, he sold these shares at a profit ${ }^{15}$ The SEC contended that the sequence of purchase, recommendation, and sale itself constitutes a violation of the antifraud provisions of the Investment Advisers Act. ${ }^{16}$ The requested injunction would have prohibited the adviser from making any recommendations without disclosing to clients his interest in the stock and his intention to purchase or sell in the near future. ${ }^{17}$ The Commission did not expressly claim that the ownership of the shares influenced the recommendation, or that the adviser's purchases and sales had any effect on the market price of the stock. ${ }^{18}$ The district court denied the SEC's motion for a preliminary injunction and was affirmed by the Court of Appeals for the Second Circuit, Judge Clark dissenting. ${ }^{19}$

In applying the antifraud provisions to the activities of Capital Gains, the district court limited the import of "fraud" and "deceit" to their technical common law meaning and thus required proof of a material misrepresentation which was either intended to injure the adviser's clients or, regardless of intent, did in fact injure his clients. ${ }^{20}$ This construction was based upon a finding that since criminal penalties may be imposed for willful violations of

13. It is to be noted that the amendment is broader than the original provision in that it is not limited to activities affecting "clients or prospective clients." The amendment also specifically covers manipulative activity.

14. The facts may be found in the report of the court of appeals opinion, SEC v. Capital Gains Research Bureau, 300 F.2d 745 (2d Cir. 1961). Capital Gains is wholly owned and substantially operated by one man; limited ownership and concentration on one stock at a time would make disclosure of the adviser's interest in recommended stocks much easier than for certain other advisers. Cf., e.g., Moody's Market Report, which expresses an opinion on over a dozen stocks.

15. One bulletin made a comparison of two stocks; the adviser had purchased options on the one favorably recommended and sold short the one disparaged. Brief for Appellant, Appendix, p. 12.

16. 300 F.2d at 747 .

17. Brief for Appellant, Appendix, pp. 3, 4.

18. It is probable that if the adviser's trading had affected the market price of the securities so as to increase the cost to his clients or to reduce the value of securities they possessed, an injunction probably would have issued on the grounds that he was acting directly to the detriment of his clients. See 191 F. Supp. at 899.

19. $300 \mathrm{~F} .2 \mathrm{~d}$ at 751 .

20. "I conclude that the words 'fraud' and 'deceit' are used in their technical sense." 191 F. Supp. at 898. "Deceit" consists of a misrepresentation of a material fact, made with knowledge of its falsity, for the purpose of inducing the plaintiff to rely on it; the plaintiff may collect damages if he justifiably relies on the misrepresentation. 3 Loss, SEcuritres Regulations 1431 (2d ed. 1961). 1 Harper \& James, The Law of Torts 528 (1956). 
the act, ${ }^{21}$ section 206 was to be strictly construed in civil as well as in criminal proceedings.

The court of appeals affirmed on the narrow grounds that "injunctive relief before a trial on the merits should be granted most sparingly" and that the issuance of a preliminary injunction is a matter for the discretion of the trial judge. ${ }^{22}$ Observing, however, that "federal securities laws are to be construed broadly to effectuate their remedial purpose," the court rejected the district court's view that actual damage to clients is a factor in determining whether the antifraud provisions have been violated. It stated that the test is not gain or loss, but whether the recommendation was honest when made. ${ }^{23}$ The court refused to believe that an intention, at the time of publication, to sell was inconsistent with an announced belief that the stock was a good long-term investment or would be likely to affect the truthfulness or validity of the recommendation. ${ }^{24}$ Judge Clark dissented, criticizing the majority for ignoring the "low standard of business morality"25 exemplified by the practices of Capital Gains. Regardless of the "honesty" of the recommendation, the dissenting Judge apparently felt that the questionable appearance of this practice to the investing public was sufficient to justify the use of a wholly prospective and "non-punitive" injunctive remedy. ${ }^{26}$

In the light of the inconclusive legislative background of this act ${ }^{27}$ and the usual nonrestrictive judicial attitude toward securities regulations, ${ }^{28}$ the district court's interpretation seems incorrect. Its assertion that the SEC must

21. 191 F. Supp. at 899 , citing 54 Stat. 857 (1940), 15 U.S.C. $\$ 80 \mathrm{~b}-17$ (1958).

22. $300 \mathrm{~F} .2 \mathrm{~d}$ at 746-47. While it is true that the discretion of the trial judge is considerable in injunction cases, Hecht Co. v. Bowles, 321 U.S. 321, 327-28 (1944), it is also true that the district judge's order can be reversed if it is based upon an error of law. SEC v. Torr, S7 F.2d 446 (2d Cir. 1937); Ring v. Spina, 148 F.2d 647 (1945). It would seem, though, that unless the decision is so clear as to preclude discretion, the case should be remanded to give the trial judge an opportunity to exercise that discretion. SEC v. Torr, supra.

23. 300 F.2d at 749.

24. Presumably the SEC relies upon the defendants' subsequent sales as implying a belief that the stock analyzed was not a good purchase to be held more than six months. But even a then present intention to sell shortly after publication will not support an inference that the recommendation to others to buy and hold for the Id. at $74 \mathrm{~S}$. capital gains period was fraudulent or deceptive.

25. Id. at 751 .

26. Id. at 753 .

27. Note 2 supra. Congress had asked for a study of investment companies, and the field of investment advisers was investigated primarily in that context. Hearings, supra note 2, at 49-50. Further, the large bulk of the hearings on the original act concerned Title I of the bill, the Investment Company Act. Ibid.

28. See, e.g., Otis \& Co. v. SEC, 106 F.2d 579, 582 (6th Cir. 1939) (no reliance or damage need be shown, because the misrepresentation was directly related to the price of the stock) ; Hughes v. SEC, 174 F.2d 969, 974 (D.C. Cir. 1949) (statement to the effect that even if all clients had been satisfied, violations of fraud provisions would still have been found). 
prove either actual damage to clients or an undefined purpose of defrauding would reach only the most flagrant situations: where the adviser deliberately circulates a "dishonest" recommendation or where actual harm to some clients has occurred. Furthermore, besides the problem of tracking down one particular client who actually did rely on the advice, proof of damages is particularly difficult in securities transactions. ${ }^{29}$ This construction, moreover, seems inconsistent with the framework of the regulatory scheme; for the only civil remedy provided is an injunction which in this Act and most other SEC regulation does not prohibit injurious or intentional conduct, but rather requires disclosure of certain activities, and which, although based upon past conduct, operates wholly prospectively. If the conduct to be enjoined involves such subjective elements as wrongful intent or depends upon proof of injury to the many clients buying and selling on stock exchanges, the use of an injunction requiring only disclosure of certain future practices seems inapposite.

Although the exact interpretation given section 206 by the majority in the court of appeals is not entirely clear, Judge Clark's dissent is based upon Professor Loss's view that:

These clauses [ $\$ \S 206(1),(2)]$ are modeled on clauses (1) and (3) of $\$$ 17 (a) of the Securities Act. Consequently, everything which has been said thus far [concerning $\$ 17(a)$ of the Securities Act] ... applies with equal force to investment advisers mutatis mutandis. ${ }^{30}$

But the Investment Advisers Act and the Securities Act, which applies to sellers of securities, are not as congruent as Professor Loss implies. For instance, subsection (2) of the antifraud provision of the latter act provides:

It shall be unlawful for any person in the offer or sale of any securities ... (2) to obtain money or property by means of any untrue statement of a material fact or any omission to state a material fact necessary in order to make the statements made, in the light of the circumstances under which they were made, not misleading, ....31

The absence of this provision in the Investment Advisers Act suggests that Congress was not willing to hold advisers accountable for the negligent omission of material facts in their recommendation, presumably because they, unlike dealers, do not profit directly from their misrepresentations. ${ }^{32}$ Since the kinds of business activities regulated by the Investment Advisers Act and the Securities Act are distinct, interpretations of statutory language in respect to

29. 1 HaRper \& Janes, The LAW of ToRTS 597-602 (1956). It would seem to be especially difficult where, as in the principle case, the misrepresentation concerns not the value of the security, but the worth of the advice.

30. 3 Loss, Securities Regulations 1515 (2d ed. 1961), quoted in $300 \mathrm{~F} .2 \mathrm{~d}$ at 752.

31. 48 Stat. 84 (1933), as amended, 15 U.S.C. $\$ 77 \mathrm{q}(\mathrm{a})$ (2) (1958).

32. Brokers and dealers may frequently give advice to their customers regarding purchases, and where the person advising is also taking part in the transaction, it is apparent that a "negligent" misrepresentation may be of great benefit to the adviser-principal. If, on the other hand, the adviser has no financial stake in whether his advice is followed, a negligent misrepresentation will only hurt his reputation. 
one cannot be transplanted in toto to regulate the other. Thus it appears that neither the statutory language nor the legislative history compels acceptance of either Professor Loss's or the district court's construction of section 206. The proper approach to the task of ascertaining its meaning would seem to lie neither in precedent concerning another statute nor in the technical dictates of the common law; rather, the statute should be construed in light of the possible opportunities for abuse by investment advisers, and the availability of other tools for coping with undesirable practices.

Everyone who comes within the reach of the Investment Advisers Act may be termed a "fiduciary,"33 but the mere application of this term does not define the specific duties of an adviser. Although the act makes no such classification, the activities of investment advisers are of three general kinds: publishing bulletins which recommend the purchase or sale of specific securities for various purposes; publishing periodical reports of a factual or statistical nature; and investment counseling, i.e., exercising continuing supervisionin light of the individual client's needs-over the client's portfolio. ${ }^{34}$ It is apparent that the manager of a portfolio has a far different relationship with his client than does the publisher of corporate financial reports. The influence which an adviser wields, and the sophistication of his clientele, will thus vary greatly with the particular service he provides, as will his legal obligations. ${ }^{35}$

Both courts seem to have overlooked the significance of previous cases to the activities of Capital Gains. Even the majority of the court of appeals admitted it to be axiomatic that an adviser who recommends a stock after having been paid to do so has acted fraudulently unless he discloses the fact of compensation to his clients. ${ }^{30}$ The cases have stated that disclosure is required irrespective of the adviser's belief in the worth of the recommendation. ${ }^{37}$ The rationale underlying such cases is that when a person holds himself out as an "investment adviser," he impliedly represents that his advice is financially disinterested. ${ }^{38}$

33. See SEC Investment Advisers Act Release No. 40, p. 2 (1945).

34. Loomis, The Securities Exchange Act of 1934 and the Investment Advisers Act of 1940, 28 GEo. WAsH. L. REv. 214, 248-49 (1959). Of course, some advisers carry on more than one type of activity.

35. For a discussion of the effect of business mores on the law of misrepresentation, see generally Harper \& McNeely, A Synthesis of the Law of Misrepresentation, 22 MrNN. L. REv. 939 (1938).

36. 300 F.2d at 749, citing SEC v. Torr, 15 F. Supp. 315, 317 (S.D.N.Y. 1936), rev'd on other grousds, S7 F.2d 446 (2d Cir. 1937), and Ridgely v. Kean, 134 App. Div. 647, 119 N.Y.S. 451 (1909).

37. SEC v. Torr, supra note 36; Ridgely v. Kean, supra note 36 . This requirement has been applied to all persons who give advice or information with respect to a security. 48 Stat. 84, 15 U.S.C. $\$ \S 77 q(b)$ (1958). The statute requires the disclosure of the amount of compensation, but seems to have been construed to cover only those situations where the information seems to come from a disinterested party; thus, newspapers need not reveal the amount they receive for each advertisement describing securities. 3 Loss, SEcurItIES Regulations 1518 (2d ed. 1961).

38. The rule applies to anyone who gives advice under circumstances which lead the recipient to regard it as being disinterested. See note 37 supra. 
Disclosure of financial interest, however, reduces pro tanto the adviser's representation of disinterestedness. If an adviser is paid to recommend a stock, it is believed that such payment is likely to influence his choice of what stock to recommend, and that clients should be informed of such influences. These cases seem relevant to the situation in Capital Gains. For if the adviser recommended the stock with an expectation of financial gain arising from the effect of his advice, he too has misrepresented his advice as "disinterested." This expectation is similarly likely to influence the adviser's choice of what stock he will recommend, and, in addition, how vigorously he will tout it..$^{38}$ Relevant to a determination of whether Capital Gains had such an expectation is the potential effect on the market of his recommendation. ${ }^{40}$ The majority in the court of appeals asserted that the defendant's advice could have no effect on the market price of the recommended stock; the dissent contended that it could. ${ }^{41}$ Also to be considered here is the apparent pattern of the adviser's conduct. The majority and dissent disagreed upon the inference to be drawn from the fact that sequences of purchase, recommendation and sale occurred six times within a short period. ${ }^{42}$ It appears, then, that the divergence of views on the court stems in large part from different factual assumptions about the adviser's expectations.

Perhaps the disagreement between the majority and the dissent is rooted in a difference of opinion concerning the effect the newly granted rule-making power should have upon a court's readiness to issue an injunction. The majority intimated that it will be extremely hesitant to enjoin a practice not previously proscribed by rule; Judge Clark objected to using the existence of the rulemaking power to cut down the Commission's ability to proceed under the

39. None of the opinions makes explicit the way in which the activities of Capital Gains might influence its recommendations. Assuming that the adviser makes his recommendations in all good faith, the bias which might arise is that he may tend to recommend stocks which are most likely to rise in response to his clients' purchases, i.e., inactive stocks or issues which have relatively few shares available for day-to-day trading.

40. For the reargument, the Commission filed a brief tending to show that the "floating supply" was only a small fraction of the shares outstanding, so that even issues with a large number of shares are quite sensitive to trading pressures. See generally Supplemental Brief for Appellant.

41. The majority stated that:

[n] o one could be so naive as to believe that a small advisory service with only 5,000 subscribers could by its own recommending influence cause such stocks ... invariably and automatically to rise so that defendants could always sell their small holdings at a small profit.

300. F.2d at 748. The dissent noted that "it is significant that in each case the market did actually respond in the way desired." Id. at 752.

42. The majority apparently considered that the frequency of the activity might tend to show "dishonesty" if further evidence could be found. The dissent talks in terms of "a pattern of defendants' normal activities," perhaps implying that, whatever conclusions may be drawn as to the adviser's motive, his past successful experiences allow an inference that the adviser will expect his bulletins to have a similar effect in the future. 
statute alone. ${ }^{43}$ Although the statute provides for regulation of the trade both by rule and injunction, there clearly are situations in which the availability of a rule-making procedure should incline the courts toward refusing injunctions in the absence of rules. A court, for example, may be asked to determine the reach of an undefined statutory term where the result of this construction might be to impair the exercise of the rule-making power. ${ }^{44}$ Similarly, a court may be asked to establish precedent in an area which would be more effectively regulated with coherent and comprehensive rules promulgated by an expert body after a thorough investigation. ${ }^{45}$

The facts of Capital Gains exemplify another situation in which the existence of the rule-making power should influence a court asked to issue an injunction. In Capital Gains the SEC sought an injunction requiring disclosure of financial interest, which, since the 1960 amendments, it could have itself required by rule. The success of an investment adviser largely depends upon his reputation for honesty. Thus, where a court enjoins an adviser for engaging in "fraudulent, deceptive, or manipulative" practices, the finding as well as the judicial proceeding inflicts a serious deprivation upon him, ${ }^{46}$ even though nominally the sanction is a "prospective" injunction. The Commission may seek to prosecute a particular adviser not only to stop his deceptive activities but also to correct a widespread undesirable practice on the part of investment advisers in general. Singling out specific individuals in the latter situation may

43. 300 F.2d at 753. There is little doubt, though, that the main purpose of the amendment was to clarify the situation by enabling the Commission to make rules. See statement of Mr. Edward N. Gadsby (Chairman of the SEC), Hearings on Securities Acts Amendments Before a Subcommittee of the Honse Committee on Interstate and Foreign Commerce, 86th Cong., 1st Sess. 119 (1959); statement of Mr. Harold S. Cherry, id. at 223. The majority opinion regards the Commission as asking for a ruling which would prohibit advisers from trading in recommended securities, rather than one which would require only disclosure of such trading. $300 \mathrm{~F} .2 \mathrm{~d}$ at 749, 750.

44. If the power of the agency to define terms in a statute is an "interpretive" rulemaking power, then the court's jurisdiction to define the terms of the statute is concurrent with the agency's. Davis, Adminsstrative Law Treatise $\S 5.03$ (1958). In such a case, it would seem that a judicial holding that a particular type of conduct was not included under the terms of the statute would preclude the agency from making a contrary rule. Under the statute here, however, the Commission's power to "prescribe means reasonably designed to prevent" fraud is probably a "legislative" rule-making power, and thus subject to only a limited amount of judicial review. Ibid.

45. The Commission has already utilized its new power under the act in promulgating rules of considerable specificity and comprehensiveness in the areas to which they are directed. See Rule 206(4)-1, SEC Investment Advisers Act Release No. 121, Nov. 2, 1961; Rule 206(4)-2, SEC Investment Advisers Act Release No. 123, Feb. 27, 1962. The former prohibits certain types of advertising and specifies not only the content of what must be disclosed, but also the relative size of the printing. The latter rule specifies the procedures which an adviser must follow if he retains in his possession any securities belonging to a client.

46. Cf. New York Times, Feb. 18, 1962, § 3 (Finance), p. 1, col. 1 (report of proceedings in the principal case). See also Comment, The Statutory Injunction as an Enforcement Weapon of Federal Agencies, 57 YaLE L.J. 1023, 1043-44 (1948). 
be necessary when the statute provides only for case by case adjudication, and a judicial refusal to enjoin an individual from continuing an industry-wide practice would preclude all remedial action. But where the Commission has the power to proscribe by rule, a court can minimize the potential injustice to an individual by refusing an injunction where the disclosure sought by the SEC equally pertains to all investment advisers. It is not clear in Capital Gains whether the injunction was to prohibit the defendant from dealing in stocks which he recommends without disclosure, or whether the injunction was intended to act as a rule for all investment advisers. ${ }^{47}$ Although the SEC suggested that the conduct of Capital Gains was particularized because of the frequency of the recommendations and subsequent sales, it failed to allege that only the defendants, and not most other investment advisers, engage in such activities. Moreover, the broad terms of the injunction which the SEC requested indicates that it was not primarily concerned with the activities of Capital Gains.88 If, in fact, Capital Gains was doing no more than adhering to a practice established throughout the trade, a rule-making, not an injunctive, proceeding seems the more appropriate remedy.

47. The fact that the Commission's argument was directed toward the broad question of an "adverse interest" would seem to imply a duty applicable to all advisers; but the requirement in the proposed injunction, that the adviser disclose his intent to trade and any trading done shortly after the recommendation, might be difficult for large advisers to meet accurately. Brief for Appellant, Appendix, pp. 3, 4.

48. The duties which the injunction would place upon Capital Gains are neither feasible for all advisers, note 47 supra, nor observed by those in positions similar to the defendant. Statement of Counsel for the SEC during reargument, Feb. 22, 1962, to the effect that some advisers print lists of those securities in which they have an interest, which list may appear on the recommending bulletin or be distributed separately. Cf. New York Times, stpra note 46 , at p. 11, col. 3. There is no mention of any publisher of a similar bulletin being required to disclose intent. The importance of the connection between this requirement and the past actions of Capital Gains is not clear. 